\title{
Selection of doubled haploid black rice lines in advanced yield trial based on multivariate analysis
}

\author{
ALIM WULANDARI KARIMA ${ }^{1, \bullet}$, RATNA KARTIKA PUTRI ${ }^{2}$, BAMBANG SAPTA PURWOKO $^{2, \bullet \bullet}$, \\ ISWARI SARASWATI DEWI ${ }^{3}$, WILLY BAYUARDI SUWARNO ${ }^{2}$, ANI KURNIAWATI ${ }^{2}$ \\ ${ }^{1}$ Graduate School, Institut Pertanian Bogor. Jl. Raya Dramaga, Kampus IPB, Bogor 11680, West Java, Indonesia. ^email: wdari1500@gmail.com \\ ${ }^{2}$ Department of Agronomy and Horticulture, Faculty of Agriculture, Institut Pertanian Bogor. Jl. Meranti, Kampus IPB Dramaga, Bogor 16680, \\ West Java, Indonesia. Tel./fax:+62-251-8629353, vvemail: bspurwoko@apps.ipb.ac.id \\ ${ }^{3}$ Indonesian Center for Agricultural Biotechnology and Genetic Resources Research and Development. J1. Tentara Pelajar No. 3 A, Bogor 16111, \\ West Java, Indonesia
}

Manuscript received: 26 August 2021. Revision accepted: 22 November 2021.

\begin{abstract}
Karima AW, Putri RK, Purwoko BS, Dewi IS, Suwarno WB, Kurniawati A. 2021. Selection of doubled haploid black rice lines in advanced yield trial based on multivariate analysis. Biodiversitas 22: 5425- 5431. Research on the development of black rice has not received much attention. The anther culture technique can shorten the plant breeding process and produce doubled haploid (DH) lines. The target of this study was to evaluate DH black rice lines with early maturity, good agronomic performance, and high yields. Twentyseven doubled haploid lines and three check varieties (Aek Sibundong, Inpari 24, and Jeliteng) were evaluated at two locations (Kediri, East Java, and Bogor, West Java) from January to July 2020. A randomized complete block design was applied to this study with three replicates. The combined analysis results showed that the genotype effect $(\mathrm{G})$ was highly significant $(\mathrm{p}<0.01)$ for all characters. In addition, all characters had a high broad-sense heritability. Characters that were positively correlated with yield based on genotypic and phenotypic correlation were the number of productive tillers, the number of vegetative tillers, panicle length, the number of filled grains, and the number of total grains. The 1000-grains weight and panicle length had a positive and the largest direct effect on yield. Principal component analysis showed that the number of productive tillers and the 1000-grains weight were related to yield. The selection index model that can be formulated is as follows $\mathrm{I}=\left(3 * 0.375^{*}\right.$ Yield $)+\left(0.723^{*} 1000\right.$-grains weight $)+(0.280 *$ Number of productive tillers $)$. Based on the selection index, 14 genotypes were selected.
\end{abstract}

Keywords: Anther culture, combined analysis of variance, correlation, functional food path analysis, principal component analysis

\section{INTRODUCTION}

Black rice, included in the Oryza sativa L., can be used as a functional food and has health-related benefits (Pratiwi and Purwestri 2017). It is because of anthocyanin content, phenolic acid, flavonoids, and antioxidant activity, which positively correlated to each other and higher than that of red and white rice (Pengkumsri et al. 2015). A study reported that the anthocyanin content in black rice is 5.121 $\pm 0.521 \mathrm{mg} \mathrm{GAE} / \mathrm{g}$, flavonoid content is $9.824 \pm 1.546 \mathrm{mg}$ $\mathrm{QE} / \mathrm{g}$ and antioxidant capacity is $6.308 \pm 0.318 \mathrm{mg}$ AEAC/g (Yuliana and Akhbar 2020). The anthocyanin is the expression of the Kala4 gene and accumulates in the pericarp (Oikawa et al. 2015). The anthocyanin can be antihyperlipidemic, antihyperglycemic, to prevent hyper diabetic syndrome in fructose-fed, and used as dietary supplements (Prasad et al. 2019). The anthocyanin in black rice has a function as an antidote to free radicals and an antioxidant. The antioxidant activity of black rice is directly proportional to its phenolic, flavonoid, and anthocyanin content (Phan et al. 2018; Priya et al. 2019).

Research on the development of black rice has not received much attention due to the limited varieties available for planting seeds, late maturity, low yield, and susceptibility to bird pests (Hanifah et al. 2016). One approach to solve this problem involves the use of biotechnology breeding techniques such as anther culture to develop black rice varieties with early maturity and high-yielding ability. The anther culture technique supported doubled haploid (DH) homozygous plants production from the $F_{1}$. Plant breeding process with anther culture technique is shorter than other conventional rice plant breeding methods which take very long time (7-10 years) to get pure lines (Dewi and Purwoko 2012). Previous researches successfully produced fertile DH lines that have good agronomic performances. Azmi et al. (2017) produced DH lines from anther culture of the F1 produced from crosses between lowland and cultivated black rice varieties. Maharani et al. (2020) induced and regenerated callus for black rice indica, while Mawaddah et al. (2018) produced the $\mathrm{DH}$ lines of red rice with high yield from anther culture. Alsabah et al. (2019) characterized DH lines in the preliminary yield test (PYT). DH lines must be evaluated further in the advanced yield test (AYT). AYT is one of the steps needed to test lines before being selected and tested in several locations to be re-selected again as potential candidates of varieties (Endelman et al. 2014).

The selection used in this research was index selection. Index selection uses several characters (secondary characters) simultaneously in a linear model. Index selection aims to increase the genotypic value in the population (Hazel et al. 1994; Sabouri et al. 2008). 
Selection can be made optimally by knowing the value of heritability, the correlation between characters, and the direct and indirect effects of a character (Silva et al. 2020). The principal component analysis is used to obtain a more effective selection index. The principal component analysis is an informative multivariate statistical tool, classifying the data individually based on the similarity and rank based on PC score. The principal component analysis also aims to minimize the number of data components that can explain the maximum variance of the overall variance (Gour et al. 2017; Alsabah et al. 2019; Inês Diel et al. 2019). This study aimed at evaluating the doubled haploid lines of black rice which is early maturing, good agronomic performance, and high yields.

\section{MATERIALS AND METHODS}

\section{Plant materials}

This study employed 27 doubled haploid lines (Table 1) obtained from the anther culture of five $F_{1}$ populations and three check varieties (Aek Sibundong, Inpari 24, and Jeliteng) as the plant materials. The study was conducted in two locations (Kediri, East Java, and Bogor, West Java, Indonesia) from January to July 2020.

\section{Procedures}

The experiment was laid out in a randomized complete block design with three replications to make 90 plots at each location. A plot of $3 \mathrm{~m} \times 3 \mathrm{~m}$ with a planting space of $25 \mathrm{~cm} \times 25 \mathrm{~cm}$ was planted with each genotype. The fertilizers used were $300 \mathrm{~kg} \mathrm{ha}^{-1}$ of urea, $100 \mathrm{~kg} \mathrm{ha}^{-1} \mathrm{KCl}$, $100 \mathrm{~kg} \mathrm{ha}^{-1} \mathrm{SP}-36$, and $50 \mathrm{~kg} \mathrm{ha}^{-1}$ NPK. Urea was applied three times at 7 days after planting (DAP), 35 DAP, and 45 DAP, $1 / 3$ dose each. $\mathrm{KCl}$ and SP-36 fertilizers were applied once at 7 DAP. NPK fertilizer was applied at 45 DAP. Harvesting was carried out when $90 \%$ of panicles had turned yellow in each experimental plot. The variables observed in this study were plant height $(\mathrm{cm})$, number of vegetative tillers, number of productive tillers, days to $50 \%$ flowering, days to harvesting, panicle length, number of filled grains per panicle, number of unfilled grains per panicle, number of total grains per panicle, 1000-grains weight, and yield $\left(\mathrm{t} \mathrm{ha}^{-1}\right)$.

\section{Data analysis}

The combined analysis of variance was conducted to study the effects of genotype, environment, and genotype $\mathrm{x}$ environment interactions. The analysis was performed using the SAS 9.4 software. The broad-sense heritability suggested if a character is suitable to be used in the selection process, and was estimated using the following formula.

$$
h_{b s}^{2}=\frac{\sigma_{g}^{2}}{\sigma_{p h}^{2}}
$$

Where: $h_{b s}^{2}$ is broad sense heritability; $\sigma_{\mathrm{g}}^{2}$ and $\sigma_{\mathrm{ph}}^{2}$ are genotypic and phenotypic variance. Heritability values are grouped into three categories, low $h_{b s}^{2} \leq 0.20$; medium
$0.20 \leq h_{b s}^{2} \leq 0.50$; and high $0.50 \leq h_{b s}^{2} \leq 1.00$ (Alsabah et al. 2019). The coefficient of variation (CV) and the genotypic coefficient of variation $(\mathrm{GCV})$ were calculated using the following formula.

$$
\begin{aligned}
& C V=\frac{\sqrt{M S E}}{\bar{x}} \times 100 \% \\
& G C V=\frac{\sqrt{\sigma_{g}^{2}}}{\bar{x}} \times 100 \%
\end{aligned}
$$

MSE was the mean square error; and $\bar{x}$ was mean for character x. According to Dabalo et al. (2020), the GCV was categorized into three categories, namely low (0-10\%), moderate (10-20\%), and high (> 20\%).

Correlation analysis was used to elucidate the linear relationship among yield and other agronomic characters. Correlation analysis was carried out in two parts, namely genotypic correlation analysis and phenotypic correlation analysis. It was to compare the influence of the environment. The genotypic and phenotypic correlation analyses were based on Kassahun et al. (2013). Path analysis was conducted to estimate the direct and indirect effects of several agronomic characters on yield (Singh and Chaudhary 2007). The R software with 'Agricolae' and 'Variability' packages was used for correlation and path analysis. The principal component analysis was a statistical multivariate technique that identified the correlation between the observed variables, classified, and compared the DH lines. The data to be analyzed were first standardized. Data standardization aimed to eliminate the units of measurement on the observed variables and convert them into the same scale. The scale was distributed symmetrically and grouped into principal components (PC) (Hamidou et al. 2018; AlNaggar et al. 2020). Principal components analysis (PCA) were performed using the correlation matrix (PérezRodríguez et al. 2020). The principal component analysis was performed using $\mathrm{R}$ 'factoextra'.

Table 1. Twenty-seven doubled haploid (DH) lines and three check varieties

\begin{tabular}{clcl}
\hline Code & \multicolumn{1}{c}{ DH lines } & Code & \multicolumn{1}{c}{ DH lines } \\
\hline 1 & MW2-7-1-1 & 16 & MW4-2-1-2 \\
2 & MW2-7-1-2 & 17 & MW4-2-2-1 \\
3 & MW2-7-1-3 & 18 & MW4-11-1-3 \\
4 & MW3-19-1-2 & 19 & MW4-11-2-3 \\
5 & MW3-24-1-1 & 20 & MW4-17-1-1 \\
6 & MW3-24-1-3 & 21 & MW4-19-1-1 \\
7 & MW3-24-1-4 & 22 & MW4-40-1-5 \\
8 & MW3-24-2-5 & 23 & MW4-53-1-1 \\
9 & MW3-32-2-4 & 24 & MW4-62-2-1 \\
10 & MW3-58-1-1 & 25 & MW5-5-1-3 \\
11 & MW3-58-1-2 & 26 & MW5-19-1-5 \\
12 & MW3-58-1-3 & 27 & MW6-8-1-1 \\
& & & Check varieties \\
13 & MW3-58-2-1 & 1 & Aek Sibundong \\
14 & MW3-58-2-5 & 2 & Inpari 24 \\
15 & MW4-2-1-1 & 3 & Jeliteng \\
\hline
\end{tabular}

Note: MW2: Leukat Itam/IR 85627-46-1-2-3, MW3: Malang/WI44, MW4: Malang/IR 85627-46-1-2-3, MW5: Purworejo/WI44, MW6: Purworejo/IR 85627-46-1-2-3 
Characters with correlations and positive effects on yield were selected simultaneously based on the weighted selection index, and then the genotypes were ranked based on their index value (Hidayatullah et al. 2018). The weighted selection index (I) was calculated using the formula according to Kang (2015).

$$
I=\sum b_{i} x_{i}=b_{1} x_{1}+b_{2} x_{2}+b_{3} x_{3} \ldots+b_{n} x_{n}
$$

$I$ is the selection index of a genotype; $b_{n}$ is the weight given to the $\mathrm{n}^{\text {th }}$ character; and $x_{n}$ is the standardized genotype mean of the $\mathrm{n}^{\text {th }}$ character. The standardized genotype means were obtained using the formula.

$$
p_{i j}=\frac{\left(x_{i j}-\bar{x}_{j}\right)}{s_{j}}
$$

Where: $p_{i j}$ is the standardized mean of the $\mathrm{i}^{\text {th }}$ genotype on $\mathrm{j}^{\text {th }}$ character; $x_{i j}$ is the mean of $\mathrm{i}^{\text {th }}$ genotype on $\mathrm{j}^{\text {th }}$ character; $\bar{x}_{j}$ is the mean of $\mathrm{j}^{\text {th }}$ character; and $s_{j}$ is the standard deviation of the $\mathrm{j}^{\text {th }}$ character.

\section{RESULTS AND DISCUSSION}

\section{Combined variance analysis and heritability}

The combined variance analysis revealed that the genotypic effect was significant $(p<0.01)$ for all characters (Table 2). Several studies have shown that the genotype had a significant effect on all observed characters (Banterng dan Joralee 2015; Akbar et al. 2019; Vaibhav et al. 2019). A significant environmental effect was observed only for the number of productive tillers, days to harvest, number of filled grains per panicle, number of total grains, 1000-grains weight, and yield (Table 2). This indicated that the genotype had a greater effect on $\mathrm{DH}$ lines performances than the environment. However, conducting experiments in various locations representing different environments is still important to select DH lines with good agronomic characteristics and high yield (Banterng and Joralee 2015).
The $\mathrm{G} \times \mathrm{E}$ interaction had a significant effect on plant height, number of filled grains, number of unfilled grains, number of total grains, days to $50 \%$ flowering, days to harvest, 1000-grains weight, and yield. The presence of interaction between genotype and environment can be challenging because the improved varieties should have high yield and superior agronomic traits in various environmental conditions (Ferreira et al. 2006; Krismawati and Arifin 2011).

The coefficient of variation $(\mathrm{CV})$ was an indicator of the reliability of the experiment (Couto et al. 2013; Kozak et al. 2013). The CV can be classified as low (CV $<5 \%)$, medium $(5 \% \leq \mathrm{CV} \leq 15 \%)$, high $(15.0 \% \leq \mathrm{CV} \leq 21.0 \%)$ and very high $(\mathrm{CV} \geq 21.0 \%)$ (Couto et al. 2013). The number of filled grains had the highest $\mathrm{CV}$ while days to harvesting were the lowest (Table 2). Besides plot homogeneity, the $\mathrm{CV}$ is also influenced by the sensitivity of the respective trait to environmental changes. The plant height, days to flowering, and days to harvest, panicle length, 1000-grains weight had a low CV, whereas the number of vegetative tillers, the number of productive tillers, number of filled grains, number of unfilled grains, number of total grains, and yield had a moderate CV.

The genotypic coefficient of variance in this study ranged from $2.91 \%$ to $61.49 \%$ (Table 3 ). The low GCV is found in the character of the number of unfilled grains, days to harvesting, and days to $50 \%$ flowering. The plant height, 1000-grains weight, and yield had moderate GCV. The number of vegetative tillers, number of productive tillers, panicle length, number of filled grains, and number of total grains had high GCV. All characters had high broad-sense heritability, ranging from 0.70 to 0.86 . This result ties well with previous studies wherein all characters of $54 \mathrm{DH}$ lines of black rice had high heritability values (Alsabah et al. 2019). According to Seyoum et al. (2012), high heritability indicated that the variability of the trait is mainly caused by the genetic factor. High heritability also indicated a small effect of environment on the expression of these characters (Ogunniyan and Olakojo 2014). Characters with high heritability values and high GCV values may be involved in the selection of the best lines (Ahsan et al. 2015).

\begin{tabular}{|c|c|c|c|c|}
\hline \multirow[b]{2}{*}{ Traits } & \multicolumn{3}{|c|}{ Mean square } & \multirow[b]{2}{*}{$\mathrm{CV}(\%)$} \\
\hline & $\begin{array}{c}\text { Genotype } \\
\text { (G) }\end{array}$ & $\begin{array}{c}\text { Environment } \\
\text { (E) }\end{array}$ & $\begin{array}{c}\text { Interaction } \\
\text { G x E }\end{array}$ & \\
\hline Plant height $(\mathrm{cm})$ & $235.15^{* *}$ & $2072.24 * *$ & $80.04 * *$ & 4.10 \\
\hline Number of vegetative tillers & $20.80 * *$ & $2141.48 * *$ & 8.85 & 13.75 \\
\hline Number of productive tillers & $17.28 * *$ & 79.33 & 4.59 & 12.84 \\
\hline Days to $50 \%$ flowering (DAS) & $19.78 * *$ & $1405.61 * *$ & $16.39 * *$ & 1.65 \\
\hline Days to harvesting (DAS) & $16.77 * *$ & 8.02 & $13.71 * *$ & 1.37 \\
\hline Number of filled grains & $1652.10 * *$ & 14796.80 & $284.09 *$ & 16.20 \\
\hline Number of unfilled grains ${ }^{\#}$ & $1.04 *$ & $204.80 * *$ & $1.33 * *$ & 14.79 \\
\hline Number of total grains & $1915.56^{* *}$ & 1002.53 & $338.06^{* *}$ & 12.26 \\
\hline 1000-grains weight & $15.0 * *$ & 0.19 & $7.75 * *$ & 6.23 \\
\hline Yield $\left(\mathrm{t} \mathrm{ha}^{-1}\right)$ & $0.92 * *$ & 0.36 & $1.78 * *$ & 10.32 \\
\hline
\end{tabular}

Table 2. Mean squares and coefficient of variations for 11 traits of DH lines of black rice

Note: $*$ and $* *$ : significant at $5 \%$ and $1 \%$ level, respectively. DAS: days after sowing. \#: data transformed by formula $(\mathrm{x}+0.5)^{0.5}$ 
Table 3. Estimates of variance components and heritability for 11 characters of DH lines of black rice

\begin{tabular}{|c|c|c|c|c|c|c|}
\hline Character & Mean & $\sigma_{g}^{2}$ & $\sigma_{\text {ge }}^{2}$ & $\sigma_{\mathrm{ph}}^{2}$ & Heritability & GCV \\
\hline $\mathrm{PH}$ & 90.65 & 232.66 & 22.08 & 282.48 & 0.82 & 16.83 \\
\hline NVT & 19.87 & 20.01 & 0.46 & 23.58 & 0.85 & 22.51 \\
\hline NPT & 15.91 & 19.66 & 0.14 & 23.01 & 0.85 & 27.86 \\
\hline DF & 84.38 & 26.77 & 4.82 & 33.64 & 0.80 & 6.13 \\
\hline $\mathrm{DH}$ & 115.47 & 21.38 & 3.73 & 26.81 & 0.80 & 4.00 \\
\hline PL & 21.39 & 50.79 & 0.29 & 59.40 & 0.86 & 33.32 \\
\hline NFG & 77.05 & 2244.49 & 42.77 & 2639.96 & 0.85 & 61.49 \\
\hline NUG & 28.05 & 0.67 & 0.25 & 0.90 & 0.74 & 2.91 \\
\hline NTG & 105.10 & 2624.47 & 57.38 & 3090.57 & 0.85 & 48.74 \\
\hline WG & 27.79 & 18.02 & 1.58 & 21.82 & 0.83 & 15.27 \\
\hline YLD & 5.46 & 0.91 & 0.49 & 1.30 & 0.70 & 17.45 \\
\hline
\end{tabular}

Note: $\sigma_{\mathrm{g}}^{2}$ : Genotypic variance; $\sigma_{\text {ge }}^{2}$ G X E interaction variance; $\sigma_{\mathrm{ph}}^{2}$ Phenotypic variance; GCV: Genotypic coefficient of variance; PH: Plant height; NVT: Number of vegetative tillers; NPT: Number of productive tillers; DF: Days to 50\% flowering; DH: Days to harvest; PL: Panicle length; NFG: Number of filled grains; NUG: Number of unfilled grains; NTG: Number of total grains; WG: 1000-grains weight; and YLD: Yield

\section{Correlation and path analyses}

The genotypic correlation coefficient was greater than the phenotypic correlation coefficient (Table 4). This was also reported by Anshori et al. (2019) for DH rice lines in saline lowland, Kole et al. (2008) on aromatic non-basmati rice, and Seyoum et al. (2012) on upland rice. The characters with a high genotypic correlation indicated that the linear relationship among these characters is mainly due to genetics rather than environmental factors (Sousa et al. 2015; Akbar et al. 2019).

The number of vegetative tillers, number of productive tillers, panicle length, number of filled grains, and number of total grains were found to be positively and significantly correlated with yield, both at genotypic and phenotypic levels (Table 4). This indicated that these characters would improve the yield of DH lines. Days to flowering had a positive and significant genotypic correlation on yield but had a non-significant phenotypic correlation with yield. It indicated that days to flowering were mainly due to genetics. The number of vegetative tillers, the number of productive tillers, days to $50 \%$ flowering, and panicle length were positively and significantly correlated with yield, which was also reported by Anshori et al. (2019). The correlation between yield with the number of filled grains, unfilled grains, and total grains was also reported by Seyoum et al. (2012). Plant height and 1000-grains weight do not have a significant correlation with yield. Tall plants may have low yield because of lodging (Dewi et al. 2009). The correlation may not provide the importance of each component in determining the yield. Path analysis was necessary to further elucidate the correlation between these traits (Bayat et al. 2017; Chen et al. 2021).

The genotypic correlations are partitioned into direct and indirect effects (Table 5) by adding 1000-grains weight. Although the 1000 -grains weight did not imply any correlation based on both correlations, it still can have another type of association or have a non-linear correlation with yield (Sousa et al. 2015). Alsabah et al. (2019) and Oladosu et al. (2018) found that the 1000-grains weight had a high and significant relationship with yield. The path analysis presented herein was based on the genotypic correlation. According to Anshori et al. (2019), the genotypic correlation was better as a basis for selection than the phenotypic correlation because there was no environmental effect.

The path analysis results (Table 5) showed that the 1000-grains weight and the panicle length had a positive and the largest direct effect on yield, which was also found by Saleh et al. (2018), Seyoum et al. (2012), and Kole et al. (2008). The number of vegetative tillers, the number of productive tillers, the number of filled grains, and the number of total grains per panicle also showed a positive direct effect on yield. Anshori et al. (2019) also reported the positive direct effect of the number of productive tillers on yield. The residual effect was high (0.77), which may be due to the effects of the incidental variables that were not observed in the study (De Barros et al. 2018), or the adverse effects of the multicollinearity in the $X^{\prime} X$ matrix (Bizeti et al. 2004). According to path analysis, the 1000grains weight, panicle length, number total of grains, number of filled grains, number of productive tillers, and number of vegetative tillers can therefore potentially be used as selection characters for yield.

\section{Selection of doubled haploid lines of black rice}

The characters with good economic value, high heritability, a positive correlation, and a large direct effect based on correlation with yield would be utilized in the selection index. In addition, PCA was observed to obtain the index weights. Several studies that used PCA to obtain character weights for the selection index model were Akbar et al. (2018), Alsabah et al. (2019), and Anshori et al. (2019). The results of the PCA showed that the first three components had eigenvalues $>1$ of the 13 principal components. This was also reported by Hamidou et al. (2018) that in their study, the first three components had eigenvalues $>1$ of the seven main components. Alsabah et al. (2019) used the principal components having eigenvalues $>1$. 
Table 4. Correlation coefficients of genotypic (below diagonal) and phenotypic (above diagonal) among characters of DH lines of black rice

\begin{tabular}{|c|c|c|c|c|c|c|c|c|c|c|c|}
\hline Character & PH & NVT & NPT & WG & NFG & NUG & NTG & PL & DF & DH & YLD \\
\hline $\mathrm{PH}$ & & $0.08^{\mathrm{ns}}$ & $-0.07^{\mathrm{ns}}$ & $0.24 *$ & $0.18^{\mathrm{ns}}$ & $-0.02^{\mathrm{ns}}$ & $0.16^{\mathrm{ns}}$ & $0.18^{\mathrm{ns}}$ & $0.44 * *$ & $0.43 * *$ & $0.18^{\mathrm{ns}}$ \\
\hline NVT & $0.10^{\mathrm{ns}}$ & & $0.9 * *$ & $0.17^{\mathrm{ns}}$ & $-0.50 * *$ & $-0.25^{*}$ & $-0.56 * *$ & $-0.52 * *$ & $-0.19^{\mathrm{ns}}$ & $-0.25^{*}$ & $-0.22 *$ \\
\hline NPT & $-0.06^{\mathrm{ns}}$ & $0.88 * *$ & & $0.19^{\mathrm{ns}}$ & $-0.63 * *$ & $-0.25^{*}$ & $-0.69 * *$ & $-0.63 * *$ & $-0.27^{*}$ & $-0.23^{*}$ & $-0.23^{*}$ \\
\hline WG & $0.36^{*}$ & $0.18^{\mathrm{ns}}$ & $0.19^{\text {ns }}$ & & $-0.21 *$ & $-0.01^{\mathrm{ns}}$ & $-0.20^{\mathrm{ns}}$ & $-0.08^{\mathrm{ns}}$ & $0.10^{\mathrm{ns}}$ & $0.10^{\mathrm{ns}}$ & $0.14^{\mathrm{ns}}$ \\
\hline NFG & $0.28^{\mathrm{ns}}$ & $-0.98 * *$ & $-0.82 * *$ & $-0.31^{\mathrm{ns}}$ & & $-0.06^{\mathrm{ns}}$ & $0.92 * *$ & $0.79 * *$ & $0.37 * *$ & $0.46^{* *}$ & $0.29 * *$ \\
\hline NUG & $-0.49 * *$ & $-0.88 * *$ & $-0.41 * *$ & $-0.15^{\mathrm{ns}}$ & $0.16^{\mathrm{ns}}$ & & $0.33 * *$ & $0.21^{\mathrm{ns}}$ & $0.20^{\mathrm{ns}}$ & $0.13^{\mathrm{ns}}$ & $0.04^{\mathrm{ns}}$ \\
\hline NTG & $0.22^{\mathrm{ns}}$ & $-0.97 * *$ & $-0.87 * *$ & $-0.29^{\mathrm{ns}}$ & $0.97 * *$ & $0.4 * *$ & & $0.83^{* *}$ & $0.43 * *$ & $0.49 * *$ & $0.30 * *$ \\
\hline PL & $0.24^{\mathrm{ns}}$ & $-0.77 * *$ & $-0.77 * *$ & $-0.07^{\mathrm{ns}}$ & $0.96 * *$ & $0.32^{\mathrm{ns}}$ & $0.96 * *$ & & $0.41 * *$ & $0.48 * *$ & $0.30 * *$ \\
\hline DF & $0.53 * *$ & $-0.49 * *$ & $-0.52 * *$ & $0.16^{\mathrm{ns}}$ & $0.50 * *$ & $0.27^{\mathrm{ns}}$ & $0.52 * *$ & $0.51 * *$ & & $0.59 * *$ & $0.20^{\mathrm{ns}}$ \\
\hline $\mathrm{DH}$ & $0.61 * *$ & $-0.62 * *$ & $-0.69 * *$ & $0.15^{\mathrm{ns}}$ & $0.73 * *$ & $0.22^{\mathrm{ns}}$ & $0.73 * *$ & $0.75^{* *}$ & $0.76^{* *}$ & & $0.32 * *$ \\
\hline YLD & $0.28^{\mathrm{ns}}$ & $-0.46^{*}$ & $-0.39 *$ & $0.34^{\mathrm{ns}}$ & $0.52 * *$ & $0.66^{\mathrm{ns}}$ & $0.52 * *$ & $0.67 * *$ & $0.44 *$ & $0.74^{\mathrm{ns}}$ & \\
\hline
\end{tabular}

Note: ns, $*$ and $* *$ : non-significant, significant at $5 \%$ and $1 \%$ level, respectively. PH: Plant height; NVT: Number of vegetative tillers; NPT: Number of productive tillers; DF: Days to 50\% flowering; DH: Days to harvesting; PL: Panicle length; NFG: Number of filled grains; NUG: Number of unfilled grains; NTG: Number of total grains; WG: 1000-grains weight; and YLD: Yield.

Table 5. Genotypic path analysis of several characters on yield of DH lines of black rice

\begin{tabular}{lccccccc}
\hline \multirow{2}{*}{ Character } & \multirow{2}{*}{ Direct effect } & \multicolumn{9}{c}{ Indirect effect } \\
\cline { 3 - 8 } & & NVT & NPT & WG & NFG & NTG & PL \\
\hline NVT & 0.114 & & 0.018 & 0.009 & -0.022 & -0.026 & -0.045 \\
NPT & 0.177 & 0.018 & & 0.015 & -0.029 & -0.036 & -0.070 \\
WG & 0.449 & 0.009 & 0.016 & & -0.027 & -0.031 & -0.016 \\
NFG & 0.197 & -0.022 & -0.029 & -0.027 & & 0.045 & 0.097 \\
NTG & 0.234 & -0.026 & -0.036 & -0.031 & 0.045 & & 0.115 \\
PL & 0.509 & -0.045 & -0.070 & -0.016 & 0.097 & 0.115 & \\
\hline
\end{tabular}

Note: NVT: Number of vegetative tillers; NPT: Number of productive tillers; PL: Panicle length; NFG: Number of filled grains; NTG: Number of total grains; WG: 1000-grains weight. Residual effect: 0.77

The estimates of the broad-sense heritability indicated that all characters were classified as highly heritable. Characters positively correlated with yield were the number of vegetative tillers, the number of productive tillers, days to flowering, panicle length, the number of filled grains, and the number of total grains. Characters with a positive and high direct effect on yield were the number of filled grains per panicle, number of productive tillers, panicle length, and 1000-grains weight. Characters with a similar direction to the yield were characters that support high yield performance (Akbar et al. 2021). The yield in PC3 was associated with the character of plant height, number of vegetative tillers, number of productive tillers, the 1000-grains weight, days to flowering, and days to harvest (Table 6).

Based on heritability, correlation analysis, path analysis, and principal component analysis, the characters used as selection characters were the number of productive tillers, 1000-grains weight, and yield. A similar approach was done by Sabouri et al. (2008) who used grain yield, 1000-grains weight, and the number of productive tillers in the selection index model on Iranian traditional rice variety. The yield was an important character in the selection, and therefore the weight of this variable was multiplied by three. This was also performed by Alsabah et al. (2019) to maximize the selection model. Therefore, the selection index model can be formulated as follows, $I=$ $(3 * 0.375 * \mathrm{YLD})+(0.723 * \mathrm{WG})+(0.280 * \mathrm{NPT})$, where
YLD is yield, WG is 1000-grains weight and NPT is number of productive tillers.

The genotype means of the selected characters were standardized and then used for calculating the selection index. Fourteen DH lines of black rice with higher index values than Aek Sibundong and Jelitheng were selected to proceed to the multilocation trial (Table 7). These lines are MW3-24-1-5, MW3-32-2-4, MW2-7-1-2. MW6-8-1-1, MW3-58-1-3, MW3-19-1-2, MW3-24-1-4, MW2-7-1-1, MW2-7-1-3, MW3- 58-1-1, MW3-24-1-1, MW4-2-1-2, MW4-53-1-1, and MW4-2-2-1. The fourteen lines had good agronomic characteristics with the mean yield of 5.2 $6.2 \mathrm{t} \mathrm{ha}^{-1}$, plant height of $88.1-102.4 \mathrm{~cm}$, number of productive tillers of $12.0-18.6$ tiller hill-1 $^{-1}$, the 1000 -grains weight of 27.5 - $29.6 \mathrm{~g}$, number of filled grains of 59.3 112.7 grain.panicle ${ }^{-1}$, panicle length of $19.3-26.90 \mathrm{~cm}$, and days to harvest of 114.7 - 120.3 days after sowing.

In conclusion, based on the results of analysis of variance, heritability values, correlation analysis, path analysis, and principal component analysis, the characters that can be used for selecting doubled-haploid rice lines of black rice are yield, 1000-grains weight, and the number of productive tillers. The selection index model was formulated as follows: $\mathrm{I}=(3 * 0.375 * \mathrm{YLD})+(0.723 * \mathrm{WG})$ $+(0.280 * \mathrm{NPT})$. Fourteen DH lines of black rice with higher index values than Aek Sibundong and Jelitheng were selected. 
Table 6. Eigenvectors, eigenvalues, and cumulative variance of the three main components from the PCA analysis of DH lines of black rice

\begin{tabular}{lccc}
\hline \multicolumn{1}{c}{ Characters } & PC1 & PC2 & PC3 \\
\hline PH & 0.325 & -0.166 & 0.751 \\
NVT & -0.782 & -0.213 & 0.332 \\
NPT & -0.849 & -0.245 & 0.280 \\
WG & -0.136 & 0.120 & 0.723 \\
NFG & 0.965 & -0.089 & -0.159 \\
NUG & 0.207 & 0.939 & -0.098 \\
NTG & 0.948 & 0.151 & -0.172 \\
PL & 0.926 & 0.154 & -0.061 \\
DF & 0.596 & 0.194 & 0.479 \\
DH & 0.742 & 0.120 & 0.467 \\
YLD & 0.516 & 0.142 & 0.375 \\
\% Cumulative variance & 48.05 & 65.192 & 80.109 \\
Eigenvalues & 6.247 & 2.228 & 1.939 \\
\hline
\end{tabular}

Note: PH: Plant height; NVT: Number of vegetative tillers; NPT: Number of productive tillers; DF: Days to 50\% flowering; DH: Days to harvest; PL: Panicle length; NFG: Number of filled grains; NUG: Number of unfilled grains; NTG: Number of total grains; WG: 1000-grains weight; and YLD: Yield

Table 7. Ranks of DH lines of black rice based on the weighted selection index

\begin{tabular}{lcccc}
\hline \multicolumn{1}{c}{ DH lines } & Yield & $\begin{array}{c}\text { Number of } \\
\text { productive } \\
\text { tillers }\end{array}$ & $\begin{array}{c}\text { Weight of } \\
\mathbf{1 0 0 0} \\
\text { grains }\end{array}$ & $\boldsymbol{I}$ \\
\hline MW 3-24-2-5 & 5.93 & 12.0 & 27.88 & 2.39 \\
MW 3-32-2-4 & 6.16 & 14.0 & 28.24 & 2.15 \\
Inpari 24 & 5.75 & 13.1 & 27.96 & 1.94 \\
MW 2-7-1-2 & 5.87 & 18.2 & 28.03 & 1.90 \\
MW6-8-1-1 & 5.37 & 16.5 & 28.99 & 1.82 \\
MW 3-58-1-3 & 5.34 & 17.4 & 27.38 & 1.73 \\
MW 3-19-1-2 & 5.55 & 17.4 & 29.08 & 1.65 \\
MW 3-24-1-4 & 6.18 & 13.5 & 29.40 & 1.09 \\
MW 2-7-1-1 & 5.99 & 16.7 & 28.88 & 0.75 \\
MW 2-7-1-3 & 5.24 & 18.6 & 29.14 & 0.43 \\
MW 3-58-1-1 & 4.66 & 15.0 & 25.02 & 0.41 \\
MW 3-24-1-1 & 5.83 & 16.0 & 29.23 & 0.37 \\
MW 4-2-1-2 & 5.58 & 18.4 & 25.78 & 0.25 \\
MW 4-53-1-1 & 5.26 & 17.4 & 28.21 & 0.18 \\
MW 4-2-2-1 & 5.32 & 13.8 & 26.74 & -0.04 \\
MW 3-58-2-5 & 5.52 & 17.1 & 27.54 & -0.15 \\
MW 3-58-2-1 & 5.51 & 14.0 & 28.08 & -0.17 \\
MW 4-17-1-1 & 5.29 & 16.2 & 28.29 & -0.21 \\
MW 4-11-1-3 & 5.01 & 16.7 & 28.36 & -0.22 \\
MW 3-24-1-3 & 5.40 & 16.8 & 27.38 & -0.28 \\
MW 5-5-1-3 & 5.02 & 15.2 & 27.01 & -0.36 \\
MW 4-11-2-3 & 4.63 & 17.7 & 29.17 & -0.92 \\
MW 4-62-2-1 & 5.18 & 17.0 & 29.54 & -0.98 \\
MW 4-2-1-1 & 5.04 & 15.2 & 28.52 & -1.21 \\
MW 4-40-1-5 & 5.51 & 16.0 & 26.69 & -1.45 \\
MW 4-19-1-1 & 5.10 & 16.1 & 25.89 & -1.73 \\
Aek Sibundong & 5.71 & 17.6 & 29.57 & -1.78 \\
MW 5-19-1-2 & 5.42 & 14.5 & 24.65 & -1.87 \\
Jelitheng & 5.89 & 14.7 & 29.77 & -1.95 \\
MW 3-58-1-2 & 5.55 & 14.8 & 23.37 & -3.73 \\
\hline Note: 1 is the & & & & \\
\hline
\end{tabular}

Note: $I$ is the weighted selection index; $I=\left(3^{*} 0.375^{*}\right.$ YLD $)+$ $(0.723 * \mathrm{WG})+(0.280 * \mathrm{NPT})$

\section{ACKNOWLEDGEMENTS}

We acknowledged the Department of Agronomy and Horticulture of IPB University, Bogor, Indonesia for facilitating the experiment. We thank the technicians for their assistance during the course of the study.

\section{REFERENCES}

Ahsan MZ, Majidano MS, Bhutto H, Soomro AW, Panhwar FH, Channa AR, Sial KB. 2015. Genetic variability, coefficient of variance, heritability and genetic advance of some Gossypium hirsutum L. accessions. J Agric Sci 7 (2): 147-151. DOI: 10.5539/jas.v7n2p147.

Akbar MR, Purwoko BS, Dewi IS, Suwarno WB, Sugiyanta. 2018. Agronomic and drought tolerance evaluation of doubled haploid rice breeding lines derived from anther culture. SABRAO J Breed Genet 50 (2): 115-128.

Akbar MR, Purwoko BS, Dewi IS, Suwarno WB, Sugiyanta. 2019. Selection of doubled haploid lines of rainfed lowland rice in preliminary yield trial. Biodiversitas 20 (10): 2796-2801. DOI: 10.13057/biodiv/d201003.

Akbar MR, Purwoko BS, Dewi IS, Suwarno WB, Sugiyanta, Anshori MF. 2021. Agronomic and yield selection of doubled haploid lines of rainfed lowland rice in advanced yield trials. Biodiversitas 22 (7): 3006-3012. DOI: 10.13057/biodiv/d220754.

Al-Naggar AMM, Shafik MM, Musa RYM. 2020. Genetic diversity based on morphological traits of 19 maize genotypes using principal component analysis and GT biplot. Annu Res Rev Biol 35 (2): 68-85. DOI: 10.9734/arrb/2020/v35i230191.

Alsabah R, Purwoko BS, Dewi IS, Wahyu Y. 2019. Selection index for selecting promising doubled haploid lines of black rice. SABRAO J Breed Genet 51 (4): 430-441.

Anshori MF, Purwoko BS, Dewi IS, Ardie SW, Suwarno WB. 2019. Selection index based on multivariate analysis for selecting doubledhaploid rice lines in lowland saline prone area. SABRAO J Breed Genet 51 (2): 161-174.

Azmi Y, Purwoko BS, Dewi IS, Syukur M, Suhartini T. 2017. Kultur antera hasil persilangan padi lokal beras hitam dengan varietas budidaya (Fatmawati dan Inpari 13). Jurnal Agronomi Indonesia 45 (3): 228-234. DOI: 10.24831/jai.v45i3.12544. [Indonesian]

Banterng P, Joralee A. 2015. Evaluation of black glutinous rice genotypes for stability of gamma oryzanol and yield in tropical environments. Turkish J Field Crop 20 (2): 142-149. DOI: 10.17557/tjfc.45719.

Bayat M, Amirnia R, Rahimi M. 2017. Phenotypic and genotypic relationships between traits in saffron (Crocus sativus L.) as revealed by path analysis. J Appl Res Med Aromat Plants 5: 33-40. DOI: 10.1016/j.jarmap.2016.10.001.

Bizeti HS, de Carvalho CGP, de Souza JRP, Destro D. 2004. Path analysis under multicollinearity in soybean. Brazilian Arch Biol Technol 47 (5): 669-676.

Chen Y, Li H, Ding H, Dong Z, Niu D, Li J. 2021. Heritability estimation and path analysis for growth traits of the razor clam Sinonovacula constricta under high salinity. Aquac 545: 737175. DOI: 10.1016/j.aquaculture.2021.737175.

Couto MF, Peternelli LA, Barbosa MHP. 2013. Classification of the coefficients of variation for sugarcane crops. Ciência Rural 43 (6): 957-961. DOI: 10.1590/s0103-84782013000600003.

Dabalo DY, Singh BCS, Weyessa B. 2020. Genetic variability and association of characters in linseed (Linum usitatissimum L.) plant grown in central Ethiopia region. Saudi J Biol Sci 27 (8): 2192-2206. DOI: 10.1016/j.sjbs.2020.06.043.

De Barros RP, Reis LS, Magalhães ICS, da Silva CG, Pereira MO, de Lira ACB, E Silva JMP, da Costa JG, Guzzo EC. 2018. Path analysis to evaluate the direct and indirect effects of climatic variables in the development stages of Tuta absoluta (Lepidoptera: Gelechiidae) in tomato (Solanum lycopersicum L.). Sci Res Essays 13 (7): 71-83. DOI: $10.5897 /$ SRE2018.6566.

Dewi IS, Purwoko BS. 2012. Kultur antera untuk percepatan perakitan varietas padi di Indonesia. Jurnal AgroBiogen 8 (2): 78-88. DOI: 10.21082/jbio.v8n2.2012.p78-88. [Indonesian]

Dewi IS, Trilaksana AC, Koesoemaningtyas T, Purwoko BS. 2009. Karakterisasi galur haploid ganda hasil kultur antera padi. Buletin 
Plasma Nutfah 15 (1): 1-12. DOI: 10.21082/blpn.v15n1.2009.p1-12. [Indonesian]

Endelman JB, Atlin GN, Beyene Y, Semagn K, Zhang X, Sorrells ME, Jannink JL. 2014. Optimal design of preliminary yield trials with genome-wide markers. Crop Sci 54 (1): 48-59. DOI 10.2135/cropsci2013.03.0154.

Ferreira DF, Demétrio CGB, Manly BFJ, Machado A de A, Vencovsky R. 2006. Statistical models in agriculture: Biometrical methods for evaluating phenotype stability in plant breeding. Lavras Cern 12 (4): 373-388.

Gour L, Maurya SB, Koutu GK, Singh SK, Shukla SS, Mishra DK. 2017. Characterization of rice (Oryza sativa L.) genotypes using principal component analysis including scree plot and rotated component matrix. Intl J Chem Stud 5 (4): 975-983.

Hamidou M, Souleymane O, Ba M, Danquah E, Kapran I, Gracen V, Ofori K. 2018. Principal component analysis of early generation sorghum lines for yield-contributing traits and resistance to midge. J Crop Improv 32 (6): $757-765 . \quad$ DOI: 10.1080/15427528.2018.1498423.

Hanifah N, Wibowo A, Setyowati N. 2016. Strategi pengembangan usaha beras hitam organik (studi kasus di kelompok tani Gemah Ripah Kecamatan Karangpandan Kabupaten Karanganyar). Agrista 4 (3): 181-191. [Indonesian]

Hazel LN, Dickerson GE, Freeman AE. 1994. The selection index-then, now, and for the future. J Dairy Sci 77 (10): 3236-3251. DOI 10.3168/jds.S0022-0302(94)77265-9.

Hidayatullah A, Purwoko BS, Dewi IS, Suwarno WB. 2018. Agronomic performance and yield of doubled haploid rice lines in advanced yield trial. SABRAO J Breed Genet 50 (3): 242-253.

Inês Diel M, Dal'col Lúcio A, Giacomini Sari B, Olivoto T, Vinícius Marques Pinheiro M, Ketzer Krysczum D, Jesus De Melo P, Schmidt D. 2019. Behavior of strawberry production with growth models: A multivariate approach. Acta Scientiarum Agronomy 43: e47812. DOI: 10.4025/actasciagron.v43i1.47812.

Kang MS. 2015. Efficient SAS programs for computing path coefficients and index weights for selection indices. J Crop Improv 29 (1): 6-22. DOI: $10.1080 / 15427528.2014 .959628$.

Kassahun B, Alemaw G, Tesfaye B. 2013. Correlation studies and path coefficient analysis for seed yield and yield components in Ethiopian coriander accessions. Afr Crop Sci J 21: 51-59. DOI 10.4314/ACSJ.V21I1

Kole P, Chakraborty N, Bhat J. 2008. Analysis of variability, correlation and path coefficients in induced mutants of aromatic non-basmati rice. Trop Agric Res Ext 11: 60-64. DOI 10.1525/curh.2008.107.712.398.

Kozak M, Bocianowski J, Rybinski W. 2013. Note on the use of coefficient of variation for data from agricultural factorial experiments. Bulg J Agric Sci 19 (4): 644-646.

Krismawati A, Arifin Z. 2011. Stabilitas hasil beberapa varietas padi di lahan sawah. Jurnal Pengkajian dan Pengembangan Teknologi Pertanian 14 (2): 84-91. DOI: 10.21082/jpptp.v14n2.2011.p.

Maharani A, Fanata WID, Laeli FN, Kim KM, Handoyo T. 2020. Callus induction and regeneration from anther cultures of Indonesian indica black rice cultivar. J Crop Sci Biotechnol 23: 21-28. DOI 10.1007/s12892-019-0322-0.

Mawaddah, Purwoko BS, Dewi IS, Wirnas D. 2018. Karakterisasi sifat agronomi tanaman padi beras merah dihaploid berpotensi hasil tingg diperoleh melalui kultur antera. Jurnal Agronomi Indonesia 46 (2): 126-132. DOI: 10.24831/jai.v46i2.16249.

Ogunniyan DJ, Olakojo SA. 2014. Genetic variation, heritability, genetic advance and agronomic character association of yellow elite inbred lines of maize (Zea mays L.). Niger J Genet 28 (2): 24-28. DOI: 10.1016/j.nigjg.2015.06.005.

Oikawa T, Maeda H, Oguchi T, Yamaguchi T, Tanabe N, Ebana K, Yano M, Ebitani T, Izawa T. 2015. The birth of a black rice gene and its local spread by introgression. Plant Cell Preview 27 (9): 2401-2414. DOI: $10.1105 /$ tpc. 15.00310

Oladosu Y, Rafii MY, Magaji U, Abdullah N, Miah G, Chukwu SC, Hussin G, Ramli A, Kareem I. 2018. Genotypic and phenotypic relationship among yield components in rice under tropical condition. Biomed Res Intl 2018: 8936767. DOI: 10.1155/2018/8936767.

Pengkumsri N, Chaiyasut C, Saenjum C, Sirilun S, Peerajan S, Suwannalert P, Sirisattha S, Sivamaruthi BS. 2015. Physicochemical and antioxidative properties of black, brown and red rice varieties of Northern Thailand. Food Sci Technol 35 (2): 331-338. DOI: 10.1590/1678-457X.6573

Pérez-Rodríguez M, Dirchwolf PM, Rodríguez-Negrín Z, Pellerano RG. 2020. Assessing mineral profiles for rice flour fraud detection by principal component analysis based data fusion. Food Chem 339: 128125. DOI: $10.1016 /$ j.foodchem.2020.128125.

Phan TT, Nguyen QT, Do TH. 2018. Agronomic characteristics, anthocyanin content, and antioxidant activity of anthocynins extracted from the seeds of black rice accessions. Vietnam J Agric Sci 1 (3): 208-219. DOI: 10.31817/vjas.2018.1.3.02.

Prasad BJ, Sharavanan PS, Sivaraj R. 2019. Health benefits of black rice a review. Grain Oil Sci Technol 2 (4): 109-113. DOI: 10.1016/j.gaost.2019.09.005.

Pratiwi R, Purwestri YA. 2017. Black rice as a functional food in Indonesia. Funct Foods Heal Dis 7 (3): 182-194. DOI: 10.31989/ffhd.v7i3.310

Priya RTS, Nelson ARLE, Ravichandran K, Antony U. 2019. Nutritional and functional properties of coloured rice varieties of South India: A review. J Ethn Foods 6: 11. DOI: 10.1186/s42779-019-0017-3.

Sabouri H, Rabiei B, Fazlalipour M. 2008. Use of selection indices based on multivariate analysis for improving grain yield in rice. Rice Sci 15 (4): 303-310. DOI: 10.1016/S1672-6308(09)60008-1.

Saleh MM, Moussa DS, Alkaraki NI, Abdurahman AL. 2018. Correlation, regression and path analysis among yield and yield traits in Triticum dicoccum. J Exp Sci 9: 24-27. DOI: 10.25081/jes.2018.v9.3653.

Seyoum M, Alamerew S, Bantte K. 2012. Genetic variability, heritability, correlation coefficient and path analysis for yield and yield related traits in upland rice (Oryza sativa L.). J Plant Sci 7 (1): 13-22. DOI: 10.3923/jps.2012.13.22

Silva MF, Maciel GM, Finzi RR, Peixoto JVM, Rezende WS, Castoldi R. 2020. Selection indexes for agronomic and chemical traits in segregating sweet corn populations. Hortic Bras 38 (1): 71-77. DOI: 10.1590/s0102-053620200111.

Singh R, Chaudhary B. 2007. Biometrical Methods in Quantitative Genetic Analysis. Kalyani Publisher, New Delhi.

Sousa LB de, Santos Junior CD, Romanato FN, Hamawaki OT, Nogueira APO, Mundim FdeM, Hamawaki RL, Hamawaki CDL. 2015. Correlation between yield components in $\mathrm{F}^{\wedge}$ soybean progenies derived from seven biparental crosses. Biosci J 31 (6): 1692-1699. DOI: $10.14393 / \mathrm{bj}-\mathrm{v} 31 \mathrm{n} 6 \mathrm{a} 2015-26217$

Vaibhav K, Satyendra, Kumar A, Singh SP, Kumar M. 2019. Morphological characterization of Katarni rice (Oryza sativa L.) derived backcross population for yield and its contributing traits. Oryza 56 (4): 368-374. DOI: 10.35709/ory.2019.56.4.4.

Yuliana ND, Akhbar MA. 2020. Chemical and physical evaluation, antioxidant and digestibility profiles of white and pigmented rice from different areas of Indonesia. Brazilian J Food Technol 23: e2018238. DOI: $10.1590 / 1981-6723.23818$ 